\title{
ZAKAT HARTA DARI HASIL UNDIAN BERHADIAH DALAM PERSPEKTIF HUKUM ISLAM
}

\author{
Muhammad Taufan Djafri \\ Sekolah Tinggi Ilmu Islam dan Bahasa Arab (STIBA) Makassar \\ muhtaufandjafri@stiba.ac.id \\ Askar Patahuddin \\ Sekolah Tinggi Ilmu Islam dan Bahasa Arab (STIBA) Makassar \\ askarfatahuddin@stiba.ac.id \\ Khaerul Aqbar \\ Sekolah Tinggi Ilmu Islam dan Bahasa Arab (STIBA) Makassar \\ khaerul@stiba.ac.id

\section{Chaeril Syarifuddin} \\ Sekolah Tinggi Ilmu Islam dan Bahasa Arab (STIBA) Makassar \\ Chaeril.syarifuddin@gmail.com
}

\begin{abstract}
Keywords : ABSTRACT

Alms, Lottery, Gifts, Assets, Sharia,

This study aims to determine the law and position of the lottery results from prizes, and to know the zakat property laws from lottery results. This study uses a qualitative library method with deductive data analysis. The research results found are as follows; First, the lottery law in Islamic law may be based on the proposition which explains that the Messenger of Allah. had done the lottery, so did the argument that explained that the Prophet Yunus had been thrown from a ship after the draw, and in general there was no argument that explained the forbidden draw. The position of the property from the lottery results is halal. Secondly, the law of issuing zakat assets from the lottery results is mandatory if the assets obtained from the lottery results do not overlap with Islamic law, for example in the category of goods that are not required to pay zakat, such as houses, land, vehicles and remain in accordance with the reckoning of the lottery results. If the gift has reached the Nisab, the zakat must apply in accordance with the provisions of gold and silver and also haul (held for a year), because this asset has become his property as a gift, which when he receives it becomes his property and is intended to be traded, this provision applies to lottery proceeds in the form of gold, silver and cash, while the rest is returned to the intention of the recipient of the prize, if he does not want to sell but only to be used, then the law that applies to the lottery results is not obligatory zakat.
\end{abstract}

\begin{tabular}{ll}
\hline Kata kunci : & \multicolumn{1}{c}{ ABSTRAK } \\
\cline { 2 - 2 } $\begin{array}{l}\text { Zakat, Undian, Hadiah, } \\
\text { Harta, Syariat, }\end{array}$ & $\begin{array}{l}\text { Penelitian dalam skripsi ini bertujuan untuk mengetahui hukum dan } \\
\text { kedudukan harta hasil undian berhadiah, dan mengetahui hukum }\end{array}$ \\
\hline
\end{tabular}


BUSTANUL FUQAHA: Jurnal Bidang Hukum Islam

Vol. 1, No. 3 (2020) : Hal. 390-415

Website: https://journal.stiba.ac.id

zakat harta dari hasil undian berhadiah. Penelitian ini menggunakan metode kualitatif pustaka dengan analisis data secara deduktif. Hasil penelitian yang ditemukan adalah sebagai berikut; Pertama, hukum undian dalam syariat Islam boleh berdasarkan dalil yang menjelaskan bahwa Rasulullah saw. pernah melakukan undian, begitu pula dalil yang menjelaskan bahwa Nabi Yunus pernah dilempar dari kapal setelah dilakukan pengundian, dan secara umum tidak ada dalil yang menjelaskan keharaman undian. Adapun kedudukan harta dari hasil undian berhadiah adalah halal. Kedua, hukum mengeluarkan zakat harta dari hasil undian berhadiah adalah wajib apabila harta yang diperoleh dari hasil undian berhadiah tidak menyelisihi syariat Islam, misalnya masuk dalam kategori barang yang tidak diwajibkan zakatnya seperti rumah, tanah, kendaraan dan tetap disesuaikan dengan nisab harta hasil undian tersebut. Jika hadiah tersebut telah dimiliki mencapai nisab maka wajib zakat berlaku sebagaimana ketentuan emas maupun perak dan juga telah haul (dimiliki selama setahun), karena harta ini telah menjadi miliknya sebagai hadiah, yang ketika dia terima, telah menjadi hartanya serta diniatkan untuk diperdagangkan, ketentuan ini berlaku untuk harta hasil undian dalam bentuk emas, perak dan uang tunai, adapun selainnya maka dikembalikan kepada niat penerima hadiah, jika dia tidak ingin menjual namun hanya untuk dipakai, maka hukum yang berlaku untuk harta hasil undian tersebut tidak wajib zakat. 


\section{PENDAHULUAN}

Agama Islam adalah Agama yang mengatur segala aspek bagi penganutnya agar terjadi keseimbangan antara kehidupan duniawi dan ukhrawi atau yang biasa diistilahkan kehidupan jasadiyah dengan kehidupan ruhiyah. Karenanya selain mengatur hubungan manusia dengan sang pencipta, Islam juga mengatur berbagai aspek kehidupan manusia, mulai dari aspek pendidikan, sosial, ekonomi, hingga politik.

Salah satu aspek sosial-ekonomi yang tidak luput dari perhatian Islam adalah pengaturan dan pengelolaan harta. Dalam perspektif Islam, harta merupakan sesuatu yang sangat penting sehingga dalam ajaran Islam ada aturan yang cukup ketat berkaitan dengan harta. mulai dari sumber dan proses mendapatkannya hingga bagaimana penggunaan dan pengeluaran harta tersebut. Berkenaan dengan hal ini, Abdurrahman bin Qādir kemudian mengelompokkan empat prinsip pengelolaan harta dalam Islam yakni: Pertama, beliau menegaskan bahwa harta benda dan semua kekayaan alam yang ada sepenuhnya adalah milik Allah swt. Kedua, dibolehkan penguasaan harta untuk kepentingan orang banyak. Ketiga, menimbun harta kekayaan adalah pelanggaran dalam agama Islam. Keempat, harta itu wajib beredar, merata, dan dibersihkan ${ }^{1}$.

Dalam hal pengelolaan harta, Agama Islam sendiri telah mensyariatkan zakat sebagai salah satu syari' at penting yang berkaitan dengan harta. Islam menjadikan zakat sebagai sarana untuk membersikan harta yang dimiliki oleh seorang muslim. Bahkan zakat merupakan rukun Islam yang ketiga setelah syahadat dan salat.

Zakat mempunyai implementasi dalam membangun kesejahteraan ummat, zakat juga menjadi perwujudan ibadah seseorang kepada Allah sekaligus sebagai perwujudan seseorang yang peduli soal ibadah, dan juga bisa dikatakan seseorang yang telah berzakat telah mempererat hubungan dengan Allah dan hubungan sesama manusia. Dengan demikian pengabdian kepada Allah adalah inti dari ibadah zakat. Zakat juga merupakan ibadah maaliyah ijtima'iyyah yang memiliki posisi yang sangat penting, baik dilihat dari sisi ajaran Ialam maupun pembangunan kesejahteraan umat. Karena itulah Abu Bakar Al-șiddiq bertekad memerangi orang-orang yang salat tetapi tidak mengeluarkan zakat. Ketegasan sikap ini menunjukkan bahwa perbuatan meninggalkan zakat adalah salah satu kedurhakaan dan jika hal ini dibiarkan maka akan memunculkan berbagai masalah sosial ekonomi dan hal yang tidak baik dalam kehidupan masyarakat. Dengan demikian, zakat bukan hanya sekedar ibadah yang wajib dilakukan oleh umat muslim melainkan juga diyakini dapat digunakan sebagai alternatif untuk mengentaskan kemiskinan ditengah-tengah masyarakat, pemberdayaan msyarakat kurang mampu dari sisi perekonomian, dan juga sebagai sarana perbaikan mental manusia muslim yang

\footnotetext{
${ }^{1}$ Abdullah bin Abdul Rahman al-Rasyid, al-Amwāl al-Mubāhah wa Ahkāmu Tamたikuhā Fi al-Syan̄'ah al-Islāmiyah,terj.Abdurrahman Qodir, Zakat Dalam Dimensi Makhdah dan social (Cet. II;Jakarta Raja Grafiindo, 2001)
} 
kemudian menjadikannya lebih tinggi dari harta tersebut, dan tidak menjadikan hamba dari harta-harta tersebut.

Di Indonesia sendiri zakat telah dikenal luas oleh masyarakat, utamanya zakat al-fitr (zakat fitrah) yang semarak digaungkan dan dikeluarkan oleh kaum muslimin pada bulan Ramadhan menjelang datangnya hari raya Idul Fitri. Selain zakat fitri, masyarakat perlu juga diingatkan tentang jenis-jenis zakat lainnya yang cukuk beragam utamanya yang berkaitan dengan zakat harta. Salah satu aspek yang menarik untuk dikaji adalah praktek undian berhadiah yang banyak dilakukan oleh lembaga keuangan seperti bank (konvensional maupun yang berbasis syariah), maupun undian berhadiah yang dilakukan oleh perusahaan dan produsen untuk menarik minat pelanggan dan menambah nilai jual dari produk barang yang dihasilkannya.

Fenomena tersebut perlu untuk mendapatkan perhatian dan kajian khusus mengingat undian tersebut secara kuantitas dapat memberikan pengaruh terhadap harta. Bagaimana status harta hasil undian berhadiah tersebut, apakah harta hasil undian tersebut termasuk dalam objek yang harus dikeluarkan zakatnya atau tidak? Dalam kajian ini penulis memberikan batasan pengertian bahwa undian berhadiah yang dimaksud adalah undian yang telah dikenal luas oleh masyarakat dan diperbolehkan oleh mayoritas ulama, serta tidak memiliki unsur-unsur (maisir) yang diharamkan oleh Islam. Berdasarkan latar belakang dan fenomena tersebut, penulis tergerak untuk melakukan kajian lebih jauh terhadap undian berhadiah dengan mengkaitkannya pada konsep zakat yang ada, serta konsekuensi syariat zakat terhadap hasil undian berhadiah tersebut.

\section{PEMBAHASAN}

\section{A. Pengertian dan Dasar Hukum Zakat}

Secara Bahasa kata zakat memiliki beberapa makna, antara lain bermakna kesucian, pujian (tazkiyah), bertambah (al ziyādah), tumbuh (al namāu), perbaikan (solāh) atau keberkahan (barakah). ${ }^{2}$ Zakat dalam makna kesucian beberapa kali disebutkan di dalam Al-Qur'an, sebagaimana disebutkan di dalam QS. Al Syams/91 : 9

Terjemahnya :

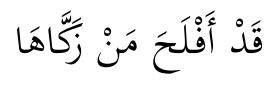

Sungguh beruntung orang yang mensucikannya(jiwa itu). ${ }^{3}$

Sedangkan di ayat yang lain Allah swt. berfirman di dalam QS. Al-A'la/87: 14

\footnotetext{
t.t.), h. 396

${ }^{2}$ Majma' Al-Lugātu Al-Arabiyah Bi Al-Qāhirah, Al-Mu'jam Al-Wasīt, Juz 1 (Dar Al-Da'wah

${ }^{3}$ Kementerian Agama Republik Indonesia, Al-Qur'an dan Terjemahnya. h. 595.
} 
Terjemahnya :

Beruntunglah orang yang mensucikan dirinya. ${ }^{4}$

Zakat dalam makna perbaikan (solāh) disebutkan contohnya oleh Al-Farra", sebagaimana firman Allah di dalam QS. Al-Kahfi/18 : 81

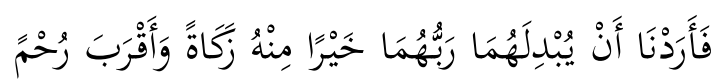

Terjemahnya :

Kemudian kami menghendaki, sekiranya tuhan mereka menggantinya dengan (seorang anak lain) yang lebih baik kesuciannya daripada (anak) itu dan lebih saying (kepada ibu bapaknya). ${ }^{5}$

Akar kata zakat berasal dari kata zakka-yazukku juga bermakna pujian, sebagaimana disebutkan di dalam firman Allah swt. QS. Al-Najm/53 : 32

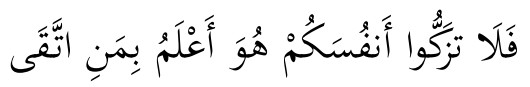

Terjemahnya :

Maka janganlah kamu menganggap dirimu suci. Dia mengetahui tentang orang yang bertakwa. ${ }^{6}$

Imam al-Nawawi di dalam kitab al-Hawi mengatakan bahwa istilah zakat adalah istilah yang telah dikenal secara 'urfoleh bangsa Arab jauh sebelum masa Islam datang. Bahkan sering disebut-sebut dalam sya'ir-sya'ir Arab jahiliyah sebelumnya. Hal yang sama dikemukakan oleh Daud Al-Zāhiri yang mengatakan bahwa kata zakat itu tidak memiliki sumber makna secara bahasa. Kata zakat itu merupakan 'urf dalam syariat Islam.

Sedangkan pengertian secara istilah menurut Yusuf al-Qārdawi sebagai mana yang dituliskan di dalam kitab Fikih al-Zakāh adalah bagian tertentu dari harta yang dimiliki yang telah Allah wajibkan untuk diberikan kepada yang mustahik (orang-orang yang berhak menerima zakat). ${ }^{7}$ Dalam Kitab Fath al-Qārib ditegaskan, zakat menurut syariat adalah nama bagi suatu harta tertentu menurut cara-cara yang tertentu, kemudian

${ }^{4}$ Kementerian Agama Republik Indonesia, Al-Qur'an dan Terjemahnya. h. 591.

${ }^{5}$ Kementerian Agama Republik Indonesia, Al-Qur'an dan Terjemahnya. h. 302.

${ }^{6}$ Kementerian Agama Republik Indonesia, Al-Qur'an dan Terjemahnya. h. 527.

${ }^{7}$ Yusuf al-Qārdawi Fikih al-Zakah Juz 1 (Al-Ḋaha 1427 H/ 2006 M ), h. 47. 
diberikan kepada sekelompok orang yang tertentu pula. ${ }^{8}$ Dalam kitab Fath al-Muin, zakat adalah nama sesuatu yang dikeluarkan (diambil) dari harta atau badan dengan ketentuan tertentu. ${ }^{9}$

Dalam kitab Kifayah al-Akhyar dirumuskan zakat adalah nama dari sejumlah harta yang tertentu yang diberikan kepada golongan tertentu dengan syarat tertentu. ${ }^{10}$ Sementara Syekh Kamil Muhammad Uwaidah menyatakan menurut bahasa zakat berarti pengembangan dan pensucian. Harta berkembang melalui zakat, tanpa disadari, di sisi lain mensucikan pelakunya dari dosa.. ${ }^{11}$ Sedangkan al-Jazīri mengatakan zakat ialah memberikan harta tertentu sebagai milik kepada orang yang berhak menerimanya dengan syarat-syarat yang ditentukan. ${ }^{12}$ Ibrāhim Muhammad al-Jamâl memaparkan zakat ialah sejumlah harta yang wajib dikeluarkan dan diberikan kepada mereka yang berhak menerimanya apabila telah mencapai nișab tertentu, dengan syarat-syarat tertentu pula. ${ }^{13}$ Sayyid Sabiq dalam kitab Fikih al-Sunnah menerangkan

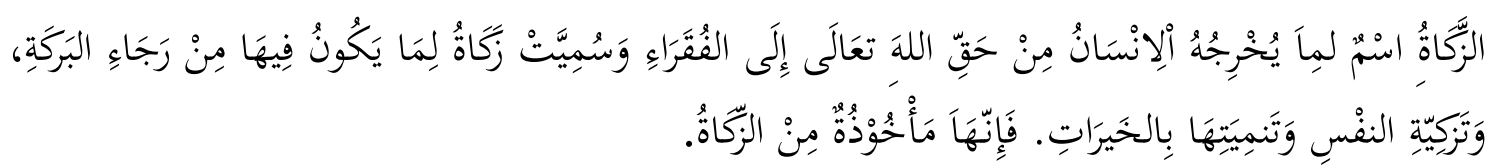

Artinya :

Zakat ialah nama atau sebutan dari sesuatu hak Allah swt. yang dikeluarkan seseorang kepada fakir miskin. Dinamakan zakat, karena di dalamnya terkandung harapan untuk memperoleh berkah, membersihkan jiwa dan memupuknya dengan berbagai kebaikan. Karena sesungguhnya hal tersebut didapatkan dari mengeluarkan zakat. ${ }^{14}$

\section{Dalil-dalil Disyariatkannya Zakat dalam Islam}

Hubungan antara pengertian zakat menurut bahasa dan dengan pengertian menurut istilah, sangat nyata dan erat sekali, yaitu bahwa harta yang dikeluarkan zakatnya akan menjadi berkah, tumbuh, berkembang dan bertambah, suci dan baik. Oleh karenanya, zakat memiliki landasan hukum dalam Al-Qur'an, hadis, dan ijma'

\footnotetext{
${ }^{8}$ Muhammad ibn Qâsim al-Gāzzi, Fath al-Qarîb alMujî̉b, (Dâr al-Ihya al-Kitab, al-Arabiah, Indonesia, t.th) h. 158.

${ }^{9}$ Zainuddin Ibn Abd Aziz al-Mâlîbary, Fath al-Mu'în, (Kairo: Maktabah Dar al-Turas, 1980), h. 50.

${ }^{10}$ Imam Taqi al-Dīn, Kifâyah al Akhyâr, (Beirut: Dâr al-Kutub al-Ilmiah, 1973), h. 386.

${ }^{11}$ Kamil Muhammad Uwaidah, Fiqih Wanita,( Jakarta:: Pustaka al-Kautsar, 1998), h. 263.

${ }^{12}$ Abdurrrahmân al-Jazirî, Kitab al-Fiqh 'alâ al-Mazâhib alArba'ah,( Beirut: Dâr al-Fikr, 1972 M), h. 449 .

${ }^{13}$ Ibrahim Muhammad al-Jamâl, Fiqh al-Mar'ah al-Muslimah,,( Semarang: CV AsySyifa, 1986 M), h. 180 .

${ }^{14}$ Sayyid Sabiq, Fiqh Sunnah, Juz I, ( Kairo: Maktabah Dar Al-Turas, t.t), h. 327.
} 


\section{a) Dalil Al-Qur'an}

Allah swt. berfirman di dalam QS. Al-Taubah/10: 103

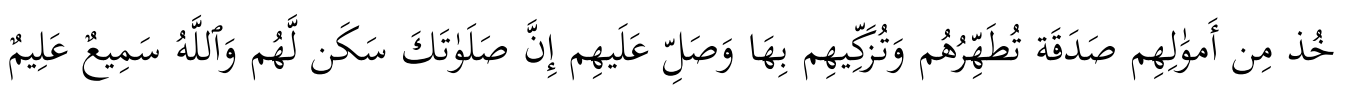

Terjemahnya :

Ambillah zakat dari harta mereka, guna membersihkan dan menyucikan mereka, dan berdoalah untuk mereka. Sesungguhnya doamu itu (menumbuhkan) ketentraman jiwa bagi mereka. Allah Maha Mendengar, Maha Mengetahui. ${ }^{15}$

Berdasarkan ayat diatas dalam tafsir Al-Muyassar dikatakan bahwa Ambilah (wahai nabi), dari sebagian harta benda orang-orang yang telah bertaubat yang mencampur adukan antara amal șalih dan perbuatan buruk lain, sedekah (zakat) yang membersihkan mereka dari kotoran dosa-dosa dan mengangkat mereka dari golongan orang-orang munafik menuju derajat orang-orang yang ikhlas, dan berdoalah kepada Allah bagi mereka untuk mengampuni dosa-dosa mereka, dan mintakanlah ampunan bagi mereka dari dosa-dosa itu. Sesungguhnya doamu dan permintaan ampunanmu akan menjadi rahmat dan ketenangan bagi mereka. Dan Allah maha mendengar tiap-tiap doa dan ucapan, maha mengetahui keadaan-keadaan hamba-hamba dan nita-niat mereka. Dan dia akan memberikan balasan kepada setiap orang yang berbuat sesuai dengan perbuatannya. ${ }^{16}$

Ambillah wahai Rasul dari harta mereka sebagai zakat yang akan membersihkan mereka dari noda-noda maksiat serta dosa dan mengembangkan kebaikan mereka. Dan panjatkanlah doa untuk mereka setelah kamu mengambil zakat dari mereka. Sesungguhnya doamu adalah rahmat dan ketentraman bagi mereka. Dan Allah Maha Mendengar doamu lagi Maha Mengetahui amal perbuatan dan niat mereka. ${ }^{17}$ Wahai Nabi, ambillah sebagian harta-harta orang-orang muslim sebagai sedekah wajib, yang menjadi sebab penghapus dosa mereka, dan mendorong mereka untuk berbuat kebaikan. Maka doakanlah dan mintakanlah ampunan bagi mereka. Sesungguhnya doa dan permohonan ampunmu itu akan menjadi sebab keteguhan diri mereka. Allah itu Maha Mendengar pengakuan mereka dan doamu untuk mereka.

Ayat tersebut bukan menunjukkan sebab khusus melainkan umum bagi seluruh harta dan seluruh manusia, karena ungkapannya menggunakan lafaz yang umum bukan

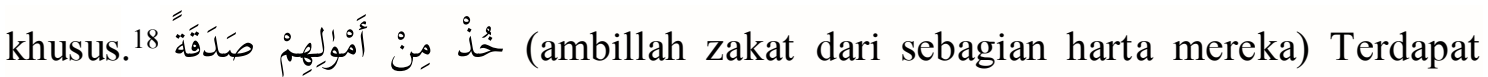

\footnotetext{
${ }^{15}$ Kementerian Agama Republik Indonesia, Al-Qur'an dan Terjemahnya. h. 203.

${ }^{16}$ Nukhbah Min al-'Ulamā, al-Tafsir al-Muyassar, (Cet. II; al-Madinah al-Munawwarah : Majma' al-Malik Fahd 1430), h. 203.

${ }^{17}$ Jamāah Min Al-'Ulamā, Al-Mukhtașar Fi Al-Tafsīr Al-Qur'an Al-Kan̄̄m,Juz 1 (Cet. III; Markaz Tafsīr Liddirāsāti Al-Qurāniyah 1436 H), h. 203.

${ }^{18}$ Abi Al-Hasan 'Ali ibn Ahmad Al-Wāhidī, Tafs̄̄r Al-Waj̄̄z, (Cet. I; Beirut Dār Al-Qālamī 1995) h. 203 .
} 
pendapat mengatakan yang dimaksud adalah zakat yang wajib dikeluarkan. Dan pendapat lain mengatakan: ini merupakan sedekah yang hanya diwajibkan atas orangorang yang mengakui kesalahannya tersebut, karena setelah penerimaan taubat mereka lalu mereka menawarkan harta mereka kepada Rasulullah, sehingga turun ayat ini yang memerintahkan Rasulullah untuk mengambil sebagian harta mereka, dan bukan

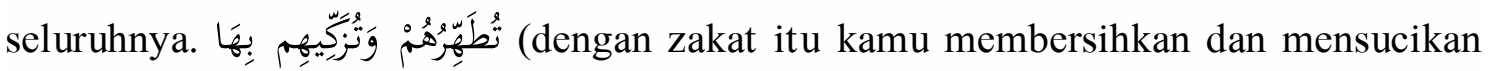
mereka) yakni kamu membersihkan mereka dari dosa-dosa mereka wahai Muhammad dengan sedekah yang diambil dari mereka. Makna pembersihan disini adalah menghilangkan bekas-bekas dosa yang masih menempel pada mereka. Adapun pensucian

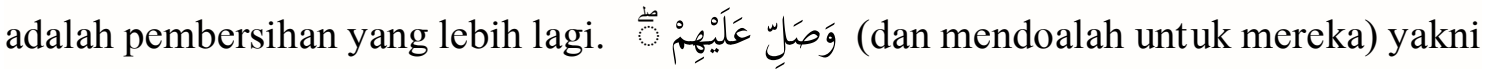
berdoalah bagi mereka setelah kami mengambil sebagian harta mereka. إِنَّ صَلَوَتَكَكَ سَكْنُ (لَّهُ ( sesungguhnya doa kamu itu (menjadi) ketenteraman jiwa bagi mereka) makna (السكن) yakni apa yang dapat menentramkan dan mendamaikan jiwa mereka. ${ }^{19}$

Kemudian di ayat yang lain Allah swt. berfirman di dalam QS. al-Baqarah/2: 43

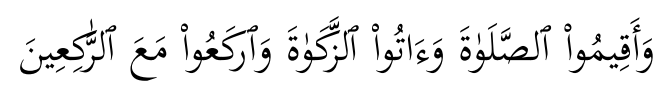

Terjemahnya :

Dan laksanakanlah salat, tunaikanlah zakat dan rukuk lah bersama orang orang yang rukuk. ${ }^{20}$

Tafsir ayat diatas menyebutkan bahwa tunaikanlah salat secara sempurna dengan melaksanakan rukun-rukunnya, wajib-wajibnya dan sunnah-sunnahnya. Bayarkanlah zakat harta yang telah Allah berikan kepada kalian. Dan tunduklah kalian kepada Allah

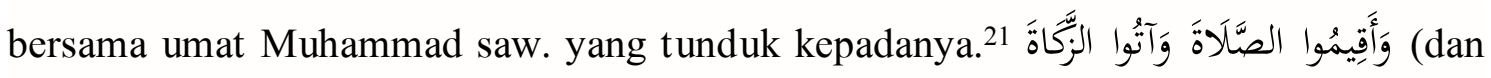
dirikanlah shalat, tunaikanlah zakat) Yakni Allah memerintahkan orang-orang Yahudi untuk memeluk Islam kemudian menjalankan salat sebagaimana yang dijelaskan oleh Nabi Muhammad saw. dan juga memerintahkan mereka untuk membayar zakat dan mengerjakan salat dalam jama'ah. وَارَزَعُوا مَعَ الرَّاكِعِينَ (dan ruku’lah beserta orang-orang yang rukuk) Karena dalam salat orang Yahudi tidak terdapat rukuk. Dan dalam ayat ini

\footnotetext{
${ }^{19}$ Muhammad Sulaiman Abdullah al-Asyqār, Zubdatu al-Tafsīr (Daulah Qatar Wizāratu al-Auqāf al-Syuūni al-Islamiyah Idaratu al-Syuūni al-Islamiyah 1428 H/2007 M ), h. 203.

${ }^{20}$ Kementerian Agama Republik Indonesia, Al-Qur'an dan Terjemahnya. h. 7.

${ }^{21}$ Nukhbah Min Al-'Ulamā, Al-Tafsir Al-Muyassar, (Cet II Al-Madinah Al-Munawwarah : Majma’ Al-Malik Fahd 1430), h. 7.
} 
terdapat petunjuk agar mengikuti salat berjama' ah bersama kaum muslimin dan pergi ke masjid. Jumhur ulama meyatakan bahwa salat berjamaah di masjid hukumnya sunnah mu'akkad karena dalam menjalankannya terdapat banyak maslahat dunia dan akhirat. ${ }^{22}$

Allah swt berfirman di dalam Q.S. Luqman/31: 4

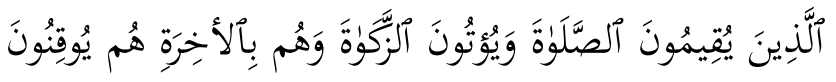

Terjemahnya :

(yaitu) orang-orang yang melaksanakan salat, menunaikan zakat dan mereka yang menyakini adanya akhirat. ${ }^{23}$

Yaitu orang-orang yang menunaikan shalat dengan sempurna pada waktunya, membayar zakat yang diwajibkan atas mereka kepada orang-orang yang berhak menerimanya, dan mereka juga beriman kepada kebangkitan dan balasan di alam akhirat. ${ }^{24}$ Yaitu orang-orang yang mengerjakan salat dengan sempurna dan memberikan zakat hartanya serta mereka meyakini adanya kebangkitan, perhitungan dan pembalasan di Akhirat. ${ }^{25}$ (Yaitu) orang-orang baik yang melaksanakan shalat secara sempurna pada waktunya, membayar zakat yang diwajibkan untuk orang-orang yang berhak dan meyakini adanya akhirat dan segala sesuatu yang ada di dalamnya berupa pembangkitan, hisab, pembalasan dan lain-lain. ${ }^{26}$

\section{b) Dalil al-Sunnah}

Rasulullah saw. bersabda

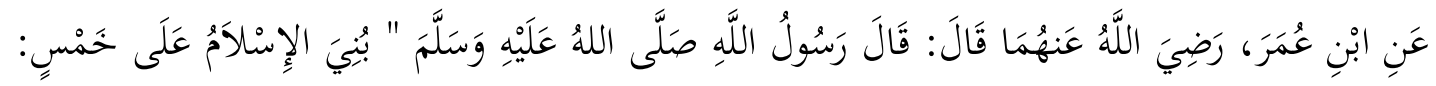

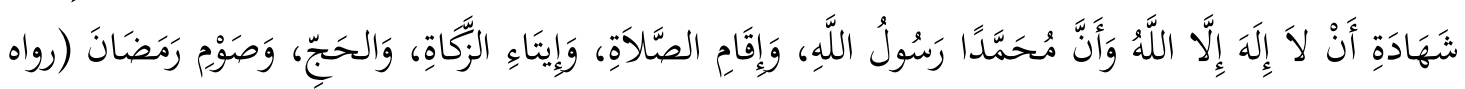

$$
\begin{aligned}
& 27 \text { (البخاري }
\end{aligned}
$$

Artinya :

\footnotetext{
${ }^{22}$ Muhammad Sulaiman Abdullah Al-Asyqār, Zubdatu Al-Tafsīr (Daulah Qatar Wizāratu AlAuqāf Al-syuūni Al-Islamiyah Idaratu Al-Syuūni Al-Islamiyah 1428 H/2007 M ), h.7.

${ }^{23}$ Kementerian Agama Republik Indonesia, Al-Qur'an dan Terjemahnya. h. 411.

${ }^{24}$ Nukhbah Min Al-'Ulamā, Al-Tafsir Al-Muyassar, (Cet II Al-Madinah Al-Munawwarah : Majma’ Al-Malik Fahd 1430), h. 411.

${ }^{25}$ Jamāah Min Al-'Ulamā, Al-Mukhtașar Fì Al-Tafsìr Al-Qur’an Al-Kañ̄m,Juz 1 (Cet. III; Markaz Tafsīr Liddirāsāti Al-Qurāniyah 1436 H), h. 411.

${ }^{26}$ Abi Al-Hasan 'Ali ibn Ahmad Al-Wāhidī, Tafs̄̄r Al-Waj̄z, (Cet. I; Beirut Dār Al-Qālamī 1995) h. 411 .

${ }^{27}$ Muhammad ibn Ismail Abu Abdillah Al-Bukhāri Al-Ju'fi, Șahih Al-Bukhāri, (Cet. I; t.t. Dār Ṭūqi Al-Najah, 1422), h. 11.
} 
Dari ibnu Umar ra. berkata, rasulullah saw. bersabda "Islam dibangun atas lima (landsan) persaksian tidak ada ilah selain Allah dan sesungguhnya Muhammad ut usan Allah, mendirikan șalat, menunaikan zakat, haji, dan puasa rāmadān. (HR.Bukhāri)

Rasulullah saw. bersabda dalam hadis yang diriwayatkan oleh Imam al-Bukhāri

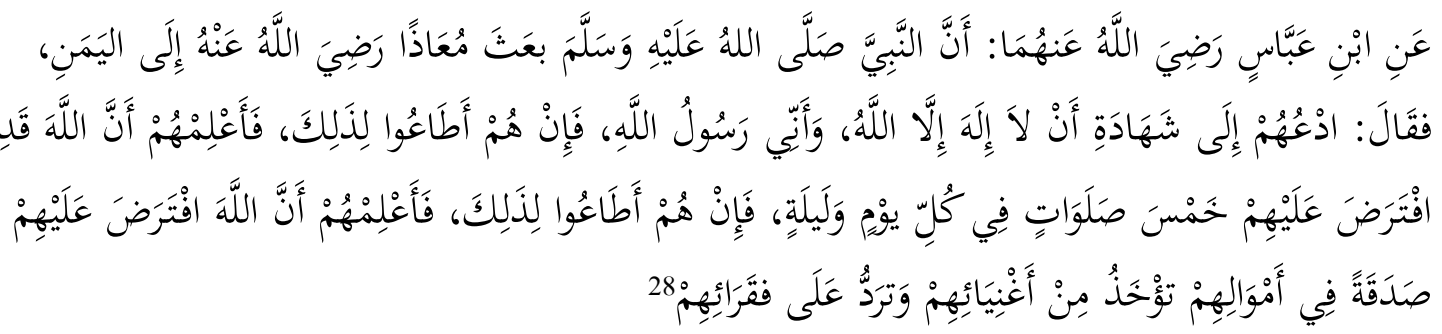

Artinya :

Dari Ibnu Abbas ra. bahwa ketika Nabi saw. mengutus Mu'ādz ra. ke negeri Yaman, beliau berkata ; Ajaklah mereka kepada syahadah (persaksian) tidak ada ilah yang berhak disembah kecuali Allah dan bahwa aku adalah utusan Allah. Jika mereka telah mentaatinya, maka beritahukanlah bahwa Allah mewajibkan atas mereka shalat lima waktu sehari semalam. dan jika mereka telah mentaatinya, maka beritahukanlah bahwa Allah mewajibkan atas mereka șadaqah (zakat) dari harta mereka yang diambil dari orang-orang kaya mereka dan diberikan kepada orang-orang faqir mereka.

\section{c) Ijma}

Seluruh umat Islam sepanjang 14 abad sepakat bulat mewajibkan zakat bagi pemeluk agama Islam, yaitu mereka yang memenuhi syarat dan hartanya termasuk memenuhi ketentuan. ${ }^{29}$ Dan seluruh sahabat sepakat untuk memerangi orang yang menolak membayarkan zakat, sebagaimana dialog antara Abu Bakar dan Umar ra.

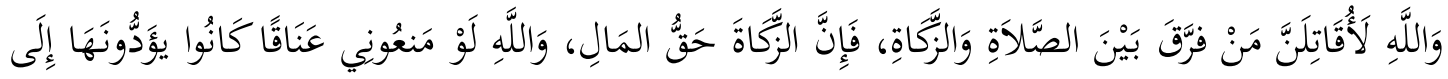

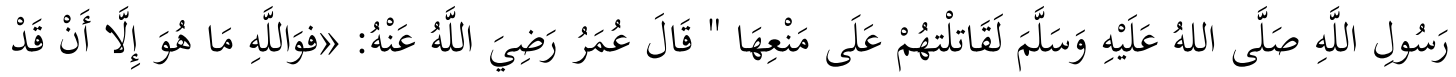

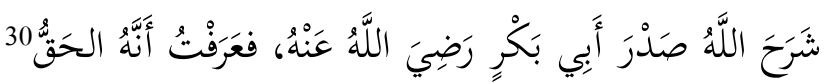

Artinya :

Demi Allah aku pasti akan memerangi siapa yang memisahkan Antara kewajiban șalat dan zakat, karena zakat adalah hak harta. Demi Allah, seandainya mereka enggan membayarkan anak kambing yang dahulu mereka menyerahkan kepada Rasulullah saw. pasti akan aku perangi mereka disebabkan keenggangan itu. Berkata 'Umar ibn al-

\footnotetext{
${ }^{28}$ Muhammad ibn Ismail Abu Abdillah Al-Bukhāri Al-Ju’fi, Șahih Al-Bukhāri, (Cet. I; t.t. Dār Ṭūqi Al-Najah, 1422), h. 104.

${ }^{29}$ Ahmad Syarwat, Seri Fikih Kehidupan (Cet 1; Jakarta: DU Publishing 2011), h. 53.

${ }^{30}$ Muhammad ibn Ismail Abu Abdillah Al-Bukhāri Al-Ju'fi, Șahih Al-Bukhāri, Juz 2 (Cet. I; t.t. Dār Ṭūqi Al-Najah, 1422), h. 105.
} 
Khattab ra. demi Allah ketegasan dia ini tidak lain selain Allah telah membukakan hati Abu Bakar al-Śiddiq ra. dan aku menyadari bahwa dia memang benar.

Al-Qur'an sendiri tidak memberi keterangan tentang kekayaan wajib zakat dan syarat-syarat apa yang mesti dipenuhi, serta tidak menjelaskan berapa besar yang harus dizakatkan, namun ketentuan-ketentuan zakat ini bisa kita lihat di dalam al-Sunnah, sebagaimana yang dituliskan dalam kitab Fathul al-Qarib al-Mujib beberapa jenis harta yang wajib untuk dikeluarkan zakatnya.

Tidak semua harta yang merupakan kekayaan wajib dikeluarkan zakatnya. Aset yang berupa benda, seperti rumah, tanah, kendaraan, tidak diwajibkan untuk dikeluarkan zakatnya. ${ }^{31}$ Zakat wajib dilakukan di dalam lima perkara, yang pertama adalah hewan ternak. Seandainya mușannif mengungkapkan dengan bahasa al-na'am', maka hal itu lebih baik karena bahasa al-na'ame itu lebih khusus cakupannya daripada bahasa alMawasyí, dan pembahasan di sini adalah di dalam binatang ternak yang lebih khusus, sedangkan yang kedua adalah al-atsman (mata uang) dan dikehendaki dengan al-atśman adalah emas dan perak, ketiga adalah al-Zuru'(hasil pertanian) dan dikehendaki dengan al-Zuru' adalah bahan makanan penguat badan, sedangkan yang keempat dan kelima adalah buah-buahan dan barang dagangan.

Secara khusus zakat harta Adalah membayar bagian tertentu, dari harta tentu, untuk golongan tertentu, dengan syarat-syarat yang tertentu dan itu adalah kewajiban, yang telah ditetapkan hukumnya. Orang yang mengerjakannya mendapat pahala dan orang yang meninggalkannya mendapat hukuman dan orang yang menentangnya akan dikafirkan. ${ }^{32}$

\section{B. Pengertian, Landasan, dan Ragam Undian Berhadiah}

Undian dalam bahasa Arab adalah al-qur'ah atau al-sahmah yang secara bahasa mempunyai arti nasib atau bagian. ${ }^{33}$ Sedangkan secara istilah syariat adalah menentukan salah satu dari beberapa orang yang sama-sama berhak terhadap sesuatu yang mungkin dibagi rata dan masing-masing tidak memiliki keistimewaan. ${ }^{34}$ Definisi di atas mengandung makna bahwa undian adalah sesuatu yang boleh dilakukan jika semua pihak memiliki hak yang salam dalam suatu hal atau permasalahan. Apabila salah satunya lebih berhak dari orang yang lain, atau sesuatu tersebut bisa dibagi rata, maka tidak

\footnotetext{
${ }^{31}$ Ahmad Syarwat, Seri Fikih Kehidupan (Cet 1; Jakarta DU Publishing 2011), h. 42.

32 Umar bin Muhammad Umar Abdul Rahman, Taysìr Kitāb al-așalat fì al-Fiqhi al-Islām (Syabakatu al-Arūka, 2016), h. 6.

${ }^{33}$ Nasywān ibn Saīd Al-Hamīra Al-Yamanī Syamsul Al- 'Ulum Wa Dawāu Al-Kalamī Al-Arabì Min Al-Kulum, Juz 5 (Cet I; Beirut: Dar Al-Fikri Wa Al-Mu'așarah 1420 H/1999 M), h. 3239.

${ }^{34}$ Taqī Al-Dīn Abu Al-Abbās Ahmad ibn Abdil Al-Halīm ibn Taimiyyah Al-Harānī, Majmu AlFatā wa, Juz 31 (t.Cet; Al-Madīnah Al-Nabawiyyah 1416 H/ 1995 M), h.269.
} 
BUSTANUL FUQAHA: Jurnal Bidang Hukum Islam

Vol. 1, No. 3 (2020) : Hal. 390-415

Website: https://journal.stiba.ac.id

diperbolehkan dengan cara undian karena berarti telah berbuat zolim kepada orang yang lebih berhak.

\section{Dalil di dalam Al-Qur'an.}

Kisah tentang pengasuhan Maryam, bahwa untuk mengetahui siapa yang akan mengasuh Maryam, maka Allah swt. menentukan dengan undian sebagaimana firmanNya dalam QS. Al-Imrān/3 : 44.

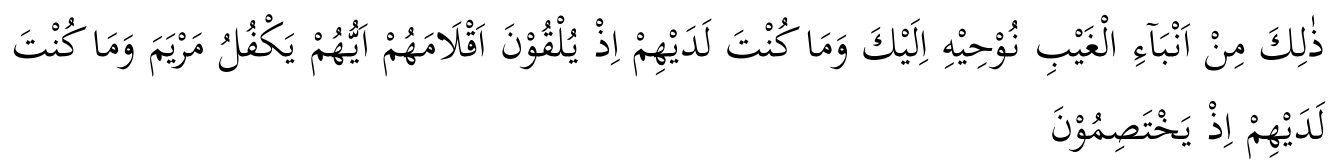

Artinya:

Itulah sebagian dari berita-berita gaib yang kami wahyukan kepadamu (Muhammad), padahal engkau tidak bersama mereka ketika mereka melemparkan pena mereka (untuk mengundi) siapa diantara mereka yang akan memilihara Maryam. Dan engkau pun tidak bersama mereka ketika mereka bertengkar. ${ }^{35}$

Dalam tafsir Al-Mukhtasār dikatakan bahwa diantara kabar gāib yang diwahyukan kepada Nabi Muhammad saw. adalah beliau tidak hadir ketika para ulama sāleh diantara mereka bersengketa tentang siapa yang lebih berhak untuk memelihara Maryam as. kemudian mereka melakukan undian dengan melemparkan anak-anak panah, sehingga keluarlah anak panah Zakaria sebagai orang yang berhak untuk memelihara Maryam. ${ }^{36}$

Kisah lain dalam Al Qur'an berkaitan dengan undian adalah kisah Nabi Yunus as. yang harus menerima nasib dengan undian tatkala kapal yang dinaikinya kelebihan beban sehingga harus ada salah satu diantara penumpangnya penumpangnya yang dilempar ke laut demi menyelamatkan seluruh penumpang kapal. Sebagaimana firman Allah swt. dalam QS. Al-Shoffat/37: 141.

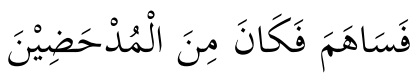

Terjemahnya :

Kemudian dia diundi ternyata dia termasuk orang-orang yang kalah (dalam undian $^{37}$

${ }^{35}$ Kementerian Agama Republik Indonesia, Al-Qur'an dan Terjemahnya. h.55.

${ }^{36}$ Nukhbah Min Al-'Ulamā Tafsīr, Al-Tafsir Al-Muyassar, Juz I (Cet. III; t.t: Markaz Tafsīr Liddirāsāti Al-Qur’aniyah 1436), h. 55.

${ }^{37}$ Kementerian Agama Republik Indonesia, Al-Qur'an dan Terjemahnya. h.451. 
Ketika kapal hampir tenggelam disebabkan terlalu banyaknya penumpang, maka mereka( penumpang kapal ) berundi agar sebagian diantara mereka dilempar keluar ke laut karena kekhawatiran mereka akan tenggelamnya kapal maka keluarlah undian Yunus sebagai orang yang harus dilempar ke laut. ${ }^{38}$

\section{Dalil di dalam As-Sunnah}

Adapun di dalam al-Sunnah, undian juga dipakai dalam beberapa hal diantaranya adalah hadits yang diriwayatkan oleh Imam al-Bukhāri, Rasulullah saw. bersabda:

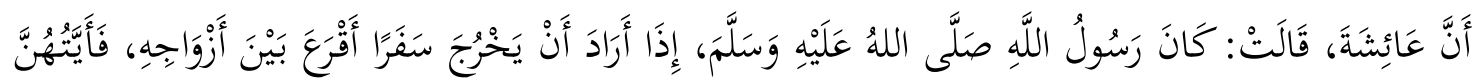

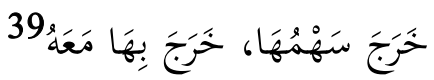

Artinya :

Dari Aisyah ra. berkata bahwasanya Rasulullah saw. apabila hendak safar (bepergian) dengan mengajak salah seorang istrinya maka beliau mengundi siapa diantara mereka yang akan menyertainya.

Dalam sebuah hadis Nabi saw. bersabda,

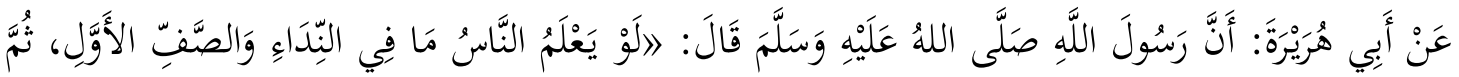

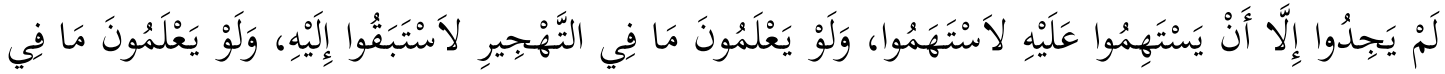

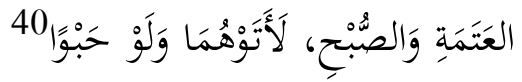

Artinya :

Dari Abi Hurairah ra. Rasulullah saw. bersabda Seandainya manusia tahu (keutamaan) ażan dan șaf pertama, kemudian mereka tidak bisa mendapatkan (adzan dan shaf pertama tersbeut) kecuali harus dengan mengundi, maka mereka pasti akan mengundi.

Adapun hadiah menurut istilah ahli fiqih adalah suatu pemberian dengan maksud memuliakan, menjalin rasa suka, menyambung tali persahabatan, atau untuk suatu kebutuhan yang lain. ${ }^{41}$ Sementara menurut pedagang serta ahli bisnis, hadiah adalah

\footnotetext{
${ }^{38}$ Nukhbah Min Al-'Ulamā Tafsīr, Al-Tafsir Al-Muyassar, Juz I (Cet. III; t.t.: Markaz Tafsīr Liddirāsāti Al-Qur’aniyah 1436), h. 451.

${ }^{39}$ Muhammad ibn Ismail Abu Abdillah Al-Bukhāri Al-Ju’fi, Șahih Al-Bukhāri, (Cet. I; t.t. Dār Ṭūqi Al-Najah, 1422), h. 101.

${ }^{40}$ Muhammad ibn Ismail Abu Abdillah Al-Bukhāri Al-Ju'fi, Șahih Al-Bukhāri, (Cet. I; t.t. Dār Țūqi Al-Najah, 1422), h. 126.

${ }^{41}$ Abdurrahman ibn Muhammad ibn Qāsim Majmu' Al-Fatāwā, Juz 31 (Madinah: Mujamma' AlMalikī Fahd Litābā'ati Al-Mushaf Al-Syarīf 1425 H/ 2005 M), h. 269.
} 
BUSTANUL FUQAHA: Jurnal Bidang Hukum Islam

Vol. 1, No. 3 (2020) : Hal. 390-415

Website: https://journal.stiba.ac.id

sesuatu yang diberikan kepada komsumen dengan maksud melariskan barang dagangannya. ${ }^{42}$

Saling memberi hadiah hukum asalnya adalah dianjurkan karena di dalamnya ada ihsan (berbuat baik) kepada sesama, sebagimana yang disebutkan dalam firman Allah swt. dalam QS. Al-Nahl/16: 90

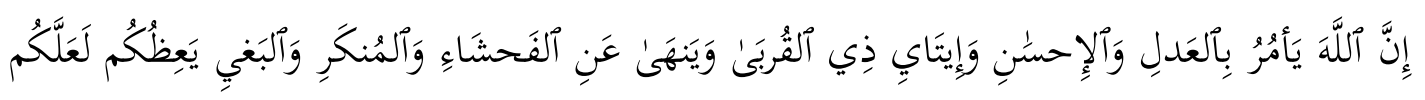

Terjemahnya :

Sesungguhnya Allah menyuruh (kamu) berlaku adil dan berbuat kebajikan, memberi bantuan kepada kerabat, dan dia melarang (melakukan) perbuatan keji, kemungkaran, dan permusuhan. Dia memberi pengajaran kepadamu agar kamu dapat mengambil pelajaran. ${ }^{43}$

Dalam ayat di atas manusia diperintahkan oleh Allah swt untuk untuk berbuat baik pada orang lain dengan memberi atau membagi nikmat yang allah swt kepada yang lainnya, karena memberi hadiah adalah salah satu bentuk nyata berbuat baik kepada orang lain, maka memberi hadiah juga diperintahkan dalam ayat tersebut. Kemudian diperjelas dengan hadis Nabi saw. bahwa kita diperintahkan untuk saling memberi hadiah karena hal itu dapat menimbulkan rasa kasing sayang dengan sesama. Dalam sebuah hadis yang diriwayatkan oleh imam al-Bukhāri dari sahabat yang mulia Abu Hurairah ra. Rasulullah saw. bersabda:

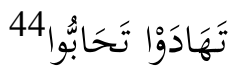

Artinya :

Saling memberi hadiahlah kalian, sehingga kalian saling mencintai.

Para ulama tidak berbeda pendapat tentang disyariatkannya menerima hadiah, akan tetapi mereka berbeda pendapat tentang hukum menerima hadiah, apakah wajib atau sunah. ${ }^{45}$

${ }^{42}$ Abu Ibrāhim Muhammad Ali Undian Berhadiah Dalam Fiqih Islam (Cet I; Gresik: Pustaka AlFurqān 1429 H), h. 8.

${ }^{43}$ Kementerian Agama Republik Indonesia, Al-Qur'an dan Terjemahnya. h. 277.

${ }^{44}$ Muhammad ibn Ismail Abu Abdillah Al-Bukhāri Al-Ju'fi, Al-Adab Al-Mufrād Bi Al-Ta'liqāt Juz 1 (Cet I; Riyād: Maktabah Al-Ma’ārif, 1419 H/ 1998 M), h. 306.

${ }^{45}$ Abu Ibrāhim Muhammad Ali Undian Berhadiah Dalam Fiqih Islam (Cet I; Gresik: Pustaka AlFurqān 1429 H), h. 10. 
Menurut Ibrahim Husen undian berhadiah adalah salah satu cara untuk menghimpun dana yang dipergunakan untuk proyek kemanusiaan dan kegiatan sosial ${ }^{46}$ Sedangkan menurut Yusuf Qardawi, undian berhadiah adalah para peserta membeli kupon seharga 10 (doolar) atau 1000 dirham. Kadang-kadang seseorang membeli lebih dari satu kupon, semakain banyak yang membeli maka kesempatan akan semakin banyak peluang untuk memperoleh hadiahnya, seperti mercedes benz, $1 \mathrm{~kg}$ emas atau barangbarang berharga lainnya yang membuat orang tertarik, pada waktu-waktu tertentu pemenang ditentukan dengan cara undian. ${ }^{47}$

Undian merupakan suatu kebiasaan yang sudah berlaku sejak dahulu, jauh sebelum datangnya agama islam. Tapi undian telah berlaku pada masa jahiliyyah itu orang yang melakukan undian untuk manantukan nasib baik atau buruk seseorang serta dilakukan didepan berhala-berhala mereka. Dalam dunia perdagangan dewasa ini, banyak pula jual beli barang dengan sistem kupon berhadiah untuk kepentingan promosi barang dagangannya. ${ }^{48}$ Dengan maksud agar konsumen tertarik dengan barang yang ditawarkan oleh pelaku usaha (produsen) dan seperti yang terjadi fenomena maraknya undian berhadiah baik dimedia elektronik maupun media cetak. Adapun aktivitas dalam undian berhadiah melibatkan hal-hal sebagai berikut:

a) Penyelenggara, biasanya pemerintah atau lembaga swasta yang legal mendapatkan izin dari pemerintah.

b) Para penyumbang, yakni orang-orang yang membeli kupon dengan mengharapkan hadiah.

Sedangkan kegiatan pihak penyelenggara undian kupon berhadiah adalah sebagai berikut:

a) Mengedarkan kupon (menjual kupon), salah satu fungsi pengedaran kupon adalah dapat dihitng dana yang diperoleh dari para penyumbang.

b) Membagi-bagi hadiah sesuai dengan ketentuan, hadiah ini diambil dari sebagian hasil dana yang diperoleh.

c) Menyalurkan dana yang telah terkumpul sesuai dengan rencana yang telah ditentukan setelah diambil untuk hadiah dan biaya operasional. ${ }^{49}$

Dalam hal ini pengertian dari undian sama dengan pengertian SMS undian berhadiah karena mempunyai praktek yang sama dan tujuan yang sama pula dimana pada SMS undian berhadiah menggunakan cara mengumpulkan dana dari konsumen untuk

\footnotetext{
${ }^{46}$ Ibrahim Husen, Ma Huwa Al-Maisir, (Jakarta: IIQ, 1987), h. 44.

${ }^{47}$ Y usuf Qardhawi, Fatwa-fatwa Kontemporer Jilid III, (Cet I; Jakarta: Abdul Hayyi Al-Khatamī, Gema Insane Press, 2002), h. 499.

${ }^{48}$ Nazar Bakry, Problematika Pelaksanaan Fiqih Islam, (Jakarta: PT Raja Grafindo Persansa, 1994), h. 78.

${ }^{49}$ Hendi Suhendi, Fiqih Mu'amalah, (Jakarta: PT. Raja Grafindo Persada, 2008), h. 318
} 
dikumulatifkan kemudian diambil dari jumlah yang terbanyak untuk mendapatkan hadiah, jadi undian atau SMS berhadiah adalah tiap-tiap kesempatan yang diadakan oleh suatu badan untuk mereka yang telah memenuhi syarat-syarat tertentu dapat ikut serta memperoleh hadiah berupa uang atau benda yang akan diberikan kepada para peserta yang ditunjuk sebagai pemenang dengan jalan diundi.

Undian berhadiah yang diadakan oleh pedagang banyak ragamnya. Ada yang membagi lembaran berisi pertanyaan yang berkaitan dengan produk, ada yang membenarkan tulisan yang salah mengenai suatu produk, ada yang mengumpulkan lembaran kupon pembelian, ada yang membagikan kupon tanpa harus membeli produknya, dan pada saat ini kita jumpai banyak kuis dan undian terutama pada musim sepak bola piala dunia, baik di koran, majalah, telivisi, atau semisalnya, kemudian lembaran-lembaran tersebut dikumpulkan dan diundi yang keluar undiannya maka dia pemenangnya. ${ }^{50}$ Secara umum ragam undian hadiah dikelompokkan menjadi dua bentuk, yakni:

a) Undian yang disyaratkan bagi peserta untuk melakukan sesuatu. Misalnya, pemilik barang dagangan memberikan lembaran yang akan diundi dengan syarat setelah pesertanya mengisi pertanyaan-pertanyaan, baik terkait dengan produknya atau tidak, atau peserta undian harus mengikuti gerak jalan, jalan sehat, reli dan lainnya. Undian yang mengharuskan bagi peserta melakukan sesuatu atau melakukan sebuah perlombaan dapat digolongkan dalam pembahasan musabaqah (perlombaan) yang terdapat hadiah di dalamnya.

b) Undian yang tidak ada keharusan pesertanya berbuat sesuatu. Misalnya, pemilik toko membagi kupon atau lembaran-lembaran yang ada nomor urutnya secara cuma-cuma dan tidak ada tuntutan bagi peserta untuk menjawab pertanyaan atau yang lainnya, kemudian diundi untuk ditentukan pemenangnya. Seperti peserta harus membeli suatu produk tertentu namun harga barang yang dibeli adalah harga standar atau tidak ditambah harganya untuk biaya undian. Seperti contoh yang lain misalnya peserta tidak disyaratkan membeli suatu produk tertentu, dan diberikan kupon undian secara cuma-cuma.

\section{Hukum dan Kedudukan Harta Hasil Undian Berhadiah}

Undian merupakan suatu kebiasaan yang sudah berlaku sejak dahulu, jauh sebelum datangnya agama Islam, sebagaimana yang Allah swt. firmankan di dalam Q.S. Al-Sāffat/37: 139-141

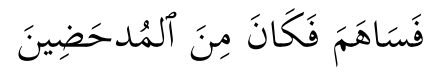

Artinya :

${ }^{50}$ Abu Ibrāhim Muhammad Ali Undian Berhadiah Dalam Fiqih Islam (Cet I; Gresik: Pustaka AlFurqān 1429 H), h. 19. 
Kemudian dia diundi ternyata dia termasuk orang-orang yang kalah (dalam undian). ${ }^{51}$

Di ayat yang lain Allah swt. berfirman di dalam Q.S. Al-Imrān/3 : 44.

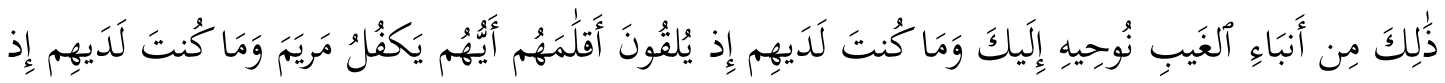

$$
\begin{aligned}
& \text { يَخَتَصْمُونَ }
\end{aligned}
$$

Artinya :

Itulah sebagian dari berita-berita gaib yang kami wahyukan kepadamu (Muhammad), padahal engkau tidak bersama mereka ketika mereka melemparkan pena mereka (untuk mengundi) siapa diantara mereka yang akan memilihara Maryam. Dan engkau pun tidak bersama mereka ketika mereka bertengkar. ${ }^{52}$

Rasulullah saw. mengundi istri-istrinya ketika hendak melakukan perjalan (safar) sebagaimana yang disebutkan dalam sebuah hadis yang diriwayatkan oleh imam alBukhāri

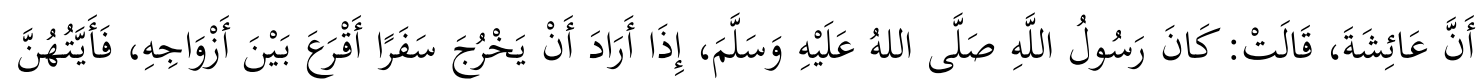

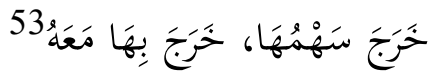

Artinya :

Dari Aisyah ra. Berkata bahwasanya Rasulullah saw. apabila hendak safar (bepergian) dengan mengajak salah seorang istrinya maka beliau mengundi siapa diantara mereka yang akan menyertainya.

Dalam hadis̀ yang lain Rasulullah saw. bersbda

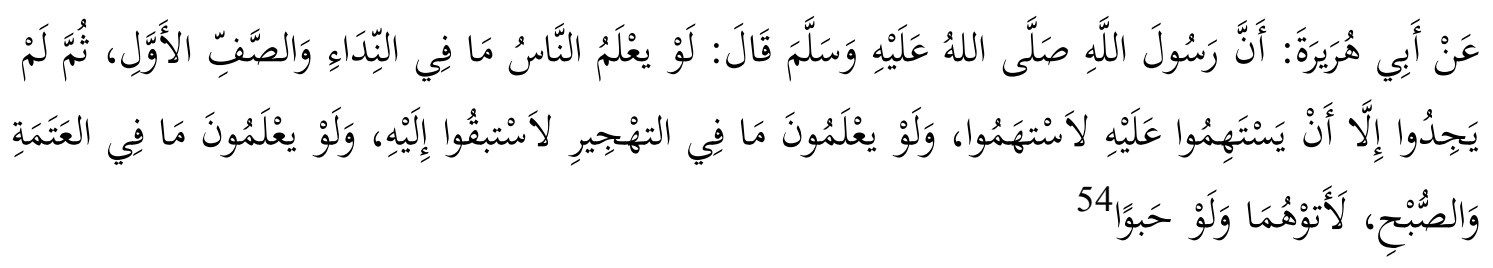

Artinya :

Dari Abi Hurairah ra. Rasulullah saw. bersabda Seandainya manusia tahu (keutamaan) ażan dan șaf pertama, kemudian mereka tidak bisa mendapatkan (adzan

\footnotetext{
${ }^{51}$ Kementerian Agama Republik Indonesia, Al-Qur'an dan Terjemahnya. h.451.

${ }^{52}$ Kementerian Agama Republik Indonesia, Al-Qur'an dan Terjemahnya. h.55.

${ }^{53}$ Muhammad ibn Ismail Abu Abdillah Al-Bukhāri Al-Ju'fi, Șahih Al-Bukhāri, (Cet. I; t.t. Dār Ṭūqi Al-Najah, 1422), h. 101.

${ }^{54}$ Muhammad ibn Ismail Abu Abdillah Al-Bukhāri Al-Ju'fi, Șahih Al-Bukhāri, (Cet. I; t.t. Dār Țūqi Al-Najah, 1422), h. 126.
} 
dan shaf pertama tersbeut) kecuali harus dengan mengundi, maka mereka pasti akan mengundi.

Dalam menyikapi permasalahan undian berhadiah, Yusuf Qārdawi membagi bentuk-bentuk hadiah menjadi tiga macam, yaitu bentuk yang diperbolehkan syariat, bentuk yang diharamkan syariat, bentuk yang diharamkan tanpa adanya perselisihan dan bentuk yang masih diperselisihkan.

\section{Bentuk yang Diperbolehkan Syariat}

Bentuk hadiah yang diperbolehkan atau diterima oleh syariat adalah hadiahhadiah yang disediakan untuk memotivasi dan mengajak kepada peningkatan ilmu pengetahuan yang bermanfaat dan amal șaleh. Misalnya, hadiah yang disediakan bagi pemenang dalam perlombaan menghafal al-Qur' an atau hadiah yang disiapkan bagi yang berprestasi dalam studi. Bisa juga sumbangan, keilmuan, sastra atau sejenisnya yang disediakan oleh pemerintah, yayasan dan individu. Semua itu diperbolehkan asalkan memotivasi dalam persaingan yang diperbolehkan syariat dalam kebaikan. ${ }^{55}$ Sebagaimana yang disebutkan dalam hadis Nabi saw. bersabda

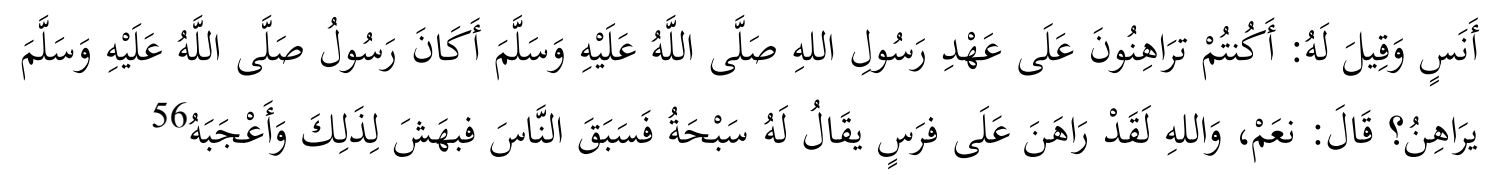

Artinya :

Dari Anas Ibn Malik ra. berkata dia ditanya, pernahkah kamu mengadakan lomba di masa Rasulullah saw. apakah Rasulullah ikut berlomba kuda di dalamnya? Anas menjawab ya benar, demi Allah Rasulullah saw. telah ikut lomba berkuda dengan seekor kuda miliknya yang dijuluki dengan sabhah, maka beliau menang hingga beliau kagum dan suka akan itu.

Bentuk hadiah seperti ini adalah disediakan kepada orang-orang yang memenuhi syarat tertentu. Apabila ada orang telah memenuhi syarat sesuai dengan yang sudah ditentukan oleh panitia khusus, maka dia berhak mendapatkan hadiah tersebut. Hadiah seperti ini diperbolehkan dan tidak ada perdebatan mengenai hukumnya. ${ }^{57}$

\section{Bentuk yang Diharamkan Tanpa Adanya Perselisihan}

Bentuk yang tidak diragukan keharamannya adalah jika yang membeli kupon dengan harga tertentu, banyak atau sedikit tanpa ada gantinya melainkan hanya untuk

\footnotetext{
${ }^{55}$ Y usuf al-Qārdawi Hadyu al-Islam Fatā wa al-Ma 'āsirah jilid 3 (Al-Maktab al-Islāmī Lilțabā'ah Wa al-Nasyr 1993 M), h. 499.

${ }^{56}$ Muhammad Rasyīd ibn 'Alī Ridā ibn Muhammad Syamsuddin, Tafs̄̄r al-Qur'an al-Hakìm, Juz 7 (Al-Haiah al-Mișriyyah al-‘āmmah Lilkutub 1990 M), h. 83.

${ }^{57}$ Y usuf al-Qārdawi Hadyu al-Islam Fatā wa al-Ma'āsirah jilid 3 (Al-Maktab al-Islāmī Lilțabā'ah Wa al-Nasyr 1993 M), h. 500.
} 
ikut dalam memperoleh hadiah yang disediakan berupa mobil, emas, atau lainnya. Bahkan, hal seperti ini termasuk larangan serius (bagi yang melakukannya dianggap telah melakukan dosa besar). Karena termasuk perbuatan judi, sebagaimana yang Allah swt. terangkan di dalam Q.S. Al-Baqarah/2 : 219 dan al-Mā'idah/5 : 90.

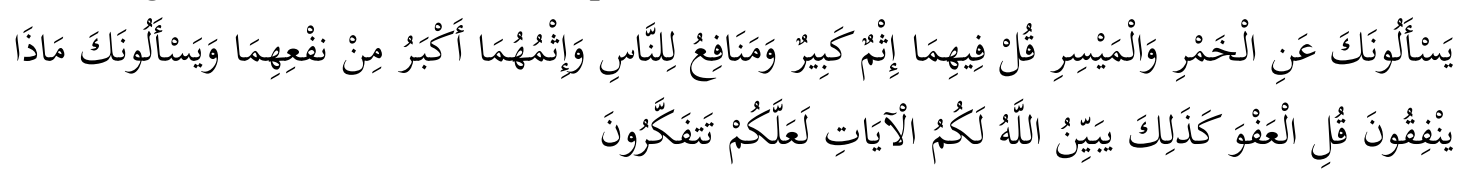

Artinya :

Mereka menanyakan kepadamu (Muhammad) tentang khamar dan judi. Katakanlah pada keduanya terdapat dosa besar dan beberapa manfaat bagi manusia. Tetapi dosanya lebih besar daripada manfaatnya. Dan mereka menanyakan kepadamu (tentang) apa yang (harus) mereka infakkan. Katakanlah kelebihan (dari apa yang diperlukan). Demikianlah Allah menerangkan ayat-ayatnya kepadamu agar memikirkan. ${ }^{58}$

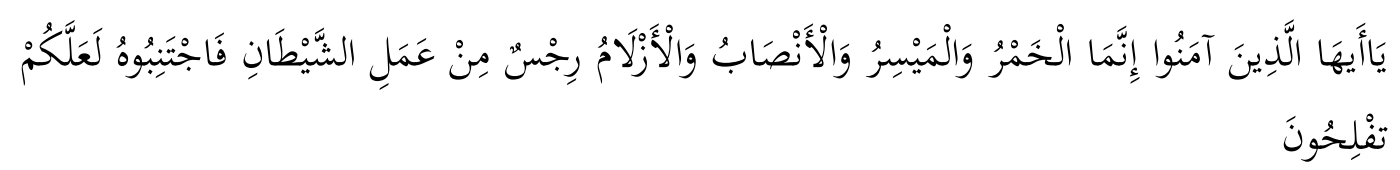

Terjemahnya :

Wahai orang-orang yang beriman sesungguhnya minuman keras, berjudi, (berkurban untuk) berhala, dan mengundi nasib dengan anak panah, adalah perbuatan keji dan termasuk perbuatan setan. Maka jauhilah (perbuatan-perbuatan) itu agar kamu beruntung. 59

\section{Bentuk yang Masih Diperselisihkan}

Bentuk undian yang masih diperselisihkan hukumnya adalah berupa kupon yang diberikan kepada seseorang sebagai ganti dari pembelian barang dari sebuah toko atau karena membeli bensin di sebuah pom bensin. Juga karena mengikuti pertandingan bola dengan membayar tiket masuk disertai dengan pembagian kupon. ${ }^{60}$

Mengundi adalah sesuatu yang di benarkan oleh syariat Islam, asalkan bukan untuk mengundi dalam bentuk perjudian. ${ }^{61}$ Mengundi yang halal itu dicontohkan oleh Rasulullah saw. ketika para sahabat berebut untuk menjadi tuan rumah bagi Rasulullah saw. saat baru tiba di madinah. Biar adil, Rasulullah saw. menawarkan untuk dilakukan sebuah pengundian dan langsung disetujui oleh para sahabat. Maka Rasulullah saw. membiarkan untanya berjalan sendirian di tengah kota madinah, dimana unta itu berhenti dan duduk maka disitulah Rasulullah akan bertempat tinggal sementara. Dan

\footnotetext{
${ }^{58}$ Kementerian Agama Republik Indonesia, Al-Qur'an dan Terjemahnya. h. 34.

${ }^{59}$ Kementerian Agama Republik Indonesia, Al-Qur'an dan Terjemahnya. h. 123.

${ }^{60}$ Yusuf al-Qārdawi Hadyu al-Islam Fatā wa al-Ma'āsirah jilid 3 (Al-Maktab al-Islāmī Lilțabā'ah Wa al-Nasyr 1993 M), h. 500.

${ }^{61}$ Ahmad Syarwat, Seri Fikih Kehidupan (Cet 1; Jakarta DU Publishing 2011), h. 120.
} 
ternyata unta itu berhenti di rumah Abu Ayyub al-Anșarī ra. Namun undian yang pada dasarnya halal bisa menjadi haram jika ada ketentuan tertentu yang menggesernya menjadi sebuah perjudian.

Sebuah undian bisa menjadi haram manakala ada keharusan bagi peserta untuk membayar sejumlah uang atau nilai tertentu kepada penyelenggara. Dan dana untuk menyediakan hadiah yang dijanjikan itu di dapat dari hasil dana yang terkumpul dari peserta undian. Maka jadilah undian itu sebuah bentuk lain dari perjudian yang diharamkan. Tetapi bila undian itu tidak mensyaratkan uang atau harta yang dipertaruhkan, alias gratis dan bisa diikuti oleh siapa saja yang memenuhi kriteria, maka hadiah dari undian itu halal dan tidak termasuk judi yang diharamkan. ${ }^{62}$ Ada beberapa macam-macam undian diantaranya:

a) Undian yang disyaratkan bagi peserta melakukan sesuatu. Misalnya, pemilik barang dagangan memberikan lembaran yang akan diundi dengan syarat pesertanya mengisi pertanyaan-pertanyaan, baik terkait dengan produknya atau tidak, atau peserta undian harus mengikuti gerak jalan, jalan sehat, reli, dan lainnya. Maka hukum undian seperti ini yang mengharuskan bagi pesertanya untuk melakukan sesuatu atau saling berlomba, maka hal ini dapat digolongkan kepada pembahasan musābaqah (perlombaan) yang terdapat hadiahnya di dalamnya. Sedangkan musābaqah di dalam Islam ada tiga pembagian (apabila digolongkan menjadi boleh atau tidaknya hadiah di dalam perlombaan itu).

1) Lomba-lomba yang disebutkan oleh Rasulullah saw. yaitu ada tiga : berkuda, memanah, dan lomba pacuan unta. Lomba-lomba yang disyariatkan dan dibolehkan adanya hadiah bagi si pemenang. Sebagaimana sabda Nabi saw.

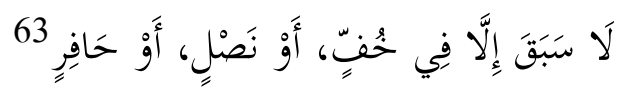

Artinya :

Tidak ada perlombaan kecuali dalam pacuan unta, kuda dan panahan.

2) Lomba yang mudaratnya lebih besar dan melalaikan manusia dari jalan Allah swt. seperti catur, permainan dadu, dan sebagainya. Lomba ini diharamkan secara mutlak, baik dengan hadiah maupun tidak.

3) Lomba yang manfaatnya lebih besar daripada mudaratnya, seperti lomba lari, renang, gulat, bela diri, balap perahu dan sebagainya, tetapi tidak disebutkan hadiahnya. ${ }^{64}$

${ }^{62}$ Ahmad Syarwat, Seri Fikih Kehidupan (Cet 1; Jakarta DU Publishing 2011), h.

${ }^{63}$ Abu Abdillah Ahmad ibn Muhammad ibn Hambal, Musnad al-Imam Ahmad ibn Hambal, Juz 16 (Cet I; Muassasatu al-Risālah 1421 H/ 2001 M), h. 129.

${ }^{64}$ Abu Ibrāhim Muhammad Ali Undian Berhadiah Dalam Fiqih Islam, (Cet I; Pustaka al-Furqān 1429 H), h. 22. 
Lomba-lomba ini disepakati oleh para ulama kebolehannya, akan tetapi yang diperselisihkan adalah apakah boleh dengan hadiah atau tidak. ${ }^{65}$ Berdasarkan dari pernyataan dan contoh-contoh di atas hukum undian berhadiah yang di dalamnya ada persyaratan bagi peserta untuk melakukan sesuatu atau berlomba, maka harus diliat perbuatan atau lomba tersebut. Apabila perbuatan atau lomba tersebut termasuk lomba yang disebutkan Nabi saw. maka diperbolehkan adanya hadiah bagi pemenangnya. Apabila pemenang lebih dari satu orang yang kesemuanya berhak mendapatkan hadiah tersebut, kemudian dilakukan pengundian untuk menentukan salah satu pemenangnya, maka hal ini hal itu juga diperbolehkan. Akan tetapi apabila lomba tersebut tidak semakna dengan lomba yang telah disebutkan oleh Nabi saw. maka tidak diperbolehkan adanya hadiah di dalamnya kecuali hadiah tersebut disediakan oleh pihak luar (bukan peserta lomba) supaya terhindar dari unsur perjudian/ mengundi nasib antara untung dan rugi.

b) Undian yang tidak ada keharusan peserta berbuat sesuatu. Misalnya pemilik toko membagi kupon atau lembaran-lembaran yang ada nomor urutnya secara CumaCuma dan tidak ada tuntutan bagi peserta untuk menjawab pertanyaan atau yang lainnya, kemudian diundi untuk ditentukan pemenangnya. Untuk mendapatkan kupon undian semacam ini terbagi menjadi dua macam ;

1) Peserta harus membeli produk tertentu. Apabila peserta undian diharuskan untuk membeli suatu produk untuk mendapatkan kupon undian, maka pendapat yang kuat adalah diperbolehkan mengikutinya ${ }^{66}$ tetapi dengan syarat. Pertama, harga barang yang dibeli adalah harga standar atau tidak ditambah harganya untuk biaya undian bila harganya ditambah, maka di dalamnya terdapat unsur perjudian karena peserta tidak lepas dari salah satu nasib untung atau rugi dan ini jelas keharamannya. Kedua, hendaknya peserta ketika hendak membeli produk tersebut bukan karena hadiahnya, akan tetapi memang betul-betul bermaksud dengan barang tersebut walaupun tanpa adanya hadiah atau undian. Hal ini lantaran orang yang tidak membutuhkan suatu barang kemudian membeli barang itu demi memperoleh hadiah atau undian, maka dia telah terjatuh dalam perjudian (Antara untung dan rugi) dan dia telah menyia-nyiakan hartanya ${ }^{67}$

${ }^{65}$ Abu Ibrāhim Muhammad Ali Undian Berhadiah Dalam Fiqih Islam, (Cet I; Pustaka al-Furqān 1429 H), h. 22.

${ }^{66}$ Abu Ibrāhim Muhammad Ali Undian Berhadiah Dalam Fiqih Islam, (Cet I; Pustaka al-Furqān 1429 H), h. 27.

${ }^{67}$ Abu Ibrāhim Muhammad Ali Undian Berhadiah Dalam Fiqih Islam, (Cet I; Pustaka al-Furqān 1429 H), h. 28. 
2) Peserta tidak disyaratkan membeli produk tertentu. Apabila peserta undian tidak dituntut untuk melakukan sesuatu dan tidak disyaratkan membeli suatu produk dan mereka mendapatkan kupon undian secara cuma-cuma, maka jelas undian semacam ini diperbolehkan karena tidak ada dalil yang melarangnya.

Adapun untuk undian SMS berhadiah maka hal ini jelas diharamkan karena peserta undian harus membayar bea pulsa, bahkan terkadang bea pulsa lebih dari nilai standar. Apalagi setelah mengirim SMS, si pengirim belum tentu mendapatkan hadiah padahal dia telah membayar bea pulsa. Hal ini termasuk perjudian atau mengundi Antara untung dan rugi. Selain itu terdapat pemborosan harta dan membuat manusia frustasi akibat hanya berpanjang angan-angan. ${ }^{68}$

Berdasarkan dalil-dalil diatas dan tidak didapati dalil yang menjelaskan tentang keharaman undian berhadiah maka praktik undian dibolehkan dalam syariat Islam selama tidak memiliki unsur yang menyelisihi syariat. Adapun kedudukan harta hasil undian berhadiah adalah halal berdasarkan kaidah fikih yang disebutkan dalam kitab alMumti' yang disusun oleh Muslim ibn Muhammad ibn Mājid al-Dausarī disebutkan kaidah

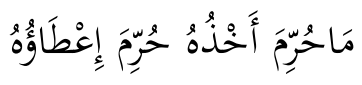
Artinya :

Apa yang diharamkan untuk diambil maka haram pula untuk diberikan. ${ }^{69}$

Dari kaidah di atas dapat dipahami bahwa apa saja yang diharamkan untuk diambil maka haram juga untuk diberikan, mafhūm al-mukhā lafah dari kaidah di atas adalah apa saja yang halal untuk diambil maka halal juga untuk diberikan. Terkait undian berhadiah jika asal hadiah tersebut bearasal dari harta yang halal, maka memberikan atau mengambil hadiah undian dibolehkan berdasarkan mafhūm al-mukhālafah dari kaidah di atas.

\section{Hukum Zakat Harta Hasil Undian Berhadiah}

Kewajiban zakat telah ditetapkan oleh Al-Qur'an, al-sunnah dan juga ijma' seluruh umat Islam. ${ }^{70}$ Sebagaimana firman Allah swt. dalam Q.S. Al-Baqarah/2: 43

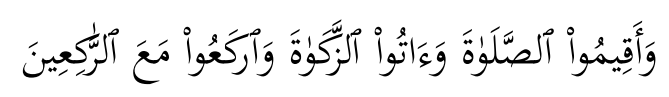
1429 H), h. 29.

${ }^{68}$ Abu Ibrāhim Muhammad Ali Undian Berhadiah Dalam Fiqih Islam, (Cet I; Pustaka al-Furqān

${ }^{69}$ Muslim ibn Muhammad ibn Mājid al-Dausarī, Al-Mumti', (Cet I; Riyad : Dar zidnī 1428 H/ 2007 M), h. 345.

${ }^{70}$ Ahmad Syarwat, Seri Fikih Kehidupan(Cet 1; Jakarta DU Publishing 2011), h.51. 
Terjemahnya :

Dan laksanakanlah salat, tunaikanlah zakat dan rukuk lah bersama orang orang yang rukuk. ${ }^{71}$

Tafsir ayat diatas menyebutkan bahwa tunaikanlah salat secara sempurna dengan melaksanakan rukun-rukunnya, wajib-wajibnya dan sunnah-sunnahnya. Bayarkanlah zakat harta yang telah Allah berikan kepada kalian. Dan tunduklah kalian kepada Allah bersama umat Muhammad saw. yang tunduk kepadanya. ${ }^{72}$ Di ayat yang lain Allah swt. berfirman dalam Q.S. Al-Taubah/10: 103

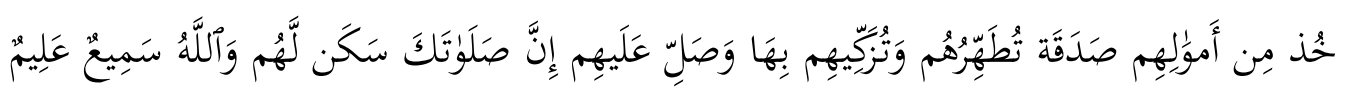

Terjemahnya :

Ambillah zakat dari harta mereka, guna membersihkan dan menyucikan mereka, dan berdoalah untuk mereka. Sesungguhnya doamu itu (menumbuhkan) ketentraman jiwa bagi mereka. Allah Maha Mendengar, Maha Mengetahui. ${ }^{73}$

Dalam hadis Rasulullah saw. bersabda

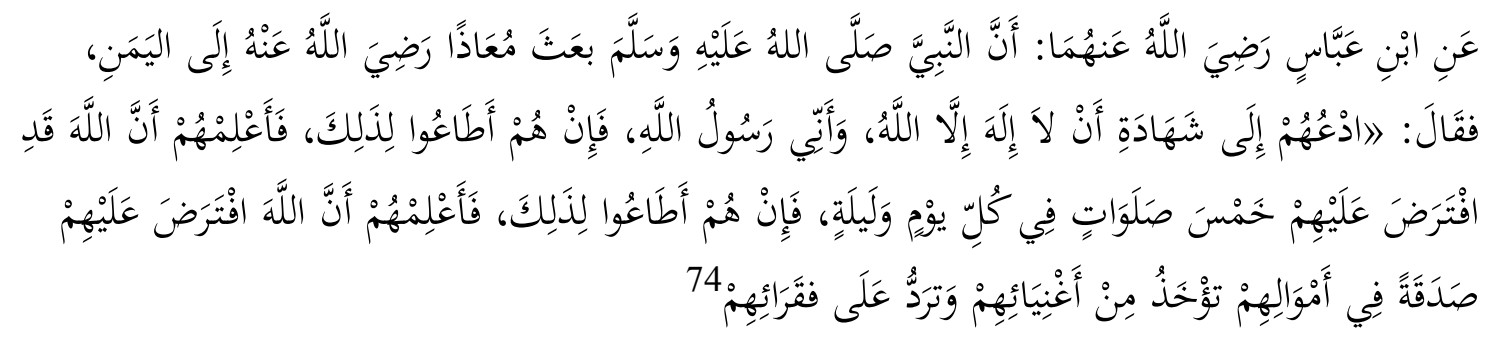

Artinya :

Dari Ibnu Abbas ra. bahwa ketika Nabi saw. mengutus Mu’ādz ra. ke negeri Yaman, beliau berkata ; Ajaklah mereka kepada syahadah (persaksian) tidak ada ilah yang berhak disembah kecuali Allah dan bahwa aku adalah utusan Allah. Jika mereka telah mentaatinya, maka beritahukanlah bahwa Allah mewajibkan atas mereka shalat lima waktu sehari semalam. dan jika mereka telah mentaatinya, maka beritahukanlah bahwa Allah mewajibkan atas mereka șadaqah (zakat) dari harta mereka yang diambil dari orang-orang kaya mereka dan diberikan kepada orang-orang faqir mereka.

${ }^{71}$ Kementerian Agama Republik Indonesia, Al-Qur'an dan Terjemahnya. h. 7.

${ }^{72}$ Nukhbah Min Al-'Ulamā, Al-Tafsir Al-Muyassar, (Cet II Al-Madinah Al-Munawwarah : Majma' Al-Malik Fahd 1430), h. 7.

${ }^{73}$ Kementerian Agama Republik Indonesia, Al-Qur'an dan Terjemahnya. h. 203.

${ }^{74}$ Muhammad ibn Ismail Abu Abdillah Al-Bukhāri Al-Ju'fi, Șahih Al-Bukhāri, (Cet. I; t.t. Dār Ṭūqi Al-Najah, 1422), h. 104. 
Dari dalil di atas dapat dipahami bahwa mengeluarkan zakat adalah kewajiban bagi mereka yang memenuhi syarat dan hartanya termasuk memenuhi ketentuan. Terkait hukum mengeluarkan zakat dari harta hasil undian berhadiah maka tidak didapati nas yang menjelaskan tentang wajibnya mengeluarkan zakat harta dari hasil undian berhadiah, namun dilihat dari mafhum al-mukhalafah dari kaidah fikih

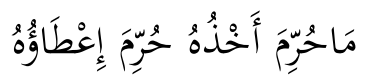

Artinya :

Apa yang diharamkan untuk diambil maka haram pula untuk diberikan.

Dipahami bahwa apa saja yang halal untuk diambil maka halal juga untuk diberikan. maka mengeluarkan zakat harta dari hasil undian berhdiah hukumnya wajib apabila harta yang didapatkan dari hasil undian tersebut tidak menyelisihi syariat dan telah memenuhi syarat dan kriteria yang ditetapkan dalam syari'at Islam.

\section{KESIMPULAN}

Dari hasil uraian di atas, dapat diambil kesimpulan bahwa: Pertama, hukum undian dalam syariat Islam boleh berdasarkan dalil yang mejelaskan bahwa Rasulullah saw. pernah melakukan undian, begitu pula dalil yang menjelaskan bahwa Nabi Yunus pernah dilempar dari kapal setelah dilakukan pengundian, dan secara umum tidak ada dalil yang menjelaskan keharaman undian. Adapun kedudukan harta dari hasil undian berhadiah adalah halal. Kedua, hukum mengeluarkan zakat harta dari hasil undian berhadiah adalah wajib apabila harta yang diperoleh dari hasil undian berhadiah tidak menyelisihi syariat Islam, misalnya masuk dalam kategori barang yang tidak diwajibkan zakatnya seperti rumah, tanah, kendaraan dan tetap disesuaikan dengan nisab harta hasil undian tersebut. Jika hadiah tersebut telah dimiliki mencapai nisab maka wajib zakat berlaku sebagaimana ketentuan emas maupun perak dan juga telah haul (dimiliki selama setahun), karena harta ini telah menjadi miliknya sebagai hadiah, yang ketika dia terima, telah menjadi hartanya serta diniatkan untuk diperdagangkan, ketentuan ini berlaku untuk harta hasil undian dalam bentuk emas, perak dan uang tunai, adapun selainnya maka dikembalikan kepada niat penerima hadiah, jika dia tidak ingin menjual namun hanya untuk dipakai, maka hukum yang berlaku untuk harta hasil undian tersebut tidak wajib zakat.

\section{DAFTAR PUSTAKA}

Abdullah, Abdul al-Rahmān bin al-Rasyid. (2001). al-Amwāl al-Mubāhah wa Ahkāmu Tamז̄kuhā Fì al-Syan̄'ah al-Islāmiyah, terj. Abdurrahman Qodir, Zakat Dalam Dimensi Makhdah dan social. Cet. II. Jakarta: Raja Grafiindo. 
BUSTANUL FUQAHA: Jurnal Bidang Hukum Islam

Vol. 1, No. 3 (2020) : Hal. 390-415

Website: https://journal.stiba.ac.id

Asyqār, Muhammad Sulaiman Abdullah. (2007). Zubdatu al-Tafsīr Daulah Qatar: Wizāratu al-Auqāf al-syuūni al-Islamiyah Idaratu al-Syuūni al-Islamiyah.

al-Dausarī, Muslim ibn Muhammad ibn Mājid. (2007). Al-Mumti', Cet I; Riyad: Dar Zidn̄̄

al-Dīn, Imam Taqi. (1973). Kifâyah al Akhyâr, Beirut: Dâr al-Kutub al-Ilmiah.

al-Gāzzi, Muhammad ibn Qâsim. (t.th). Fath al-Qarîb alMujîb, Dâr al-Ihya al-Kitab, alArabiah, Indonesia.

al-Harānī, Taqī Al-Dīn Abu Al-Abbās Ahmad ibn Abdil Al-Halīm ibn Taimiyyah. (1995). Majmu Al-Fatāwa, Juz 31. Al-Madīnah Al-Nabawiyyah.

al-Jazirî, Abdurrrahmân. (1972). Kitab al-Fiqh 'alâ al-Mazâhib alArba'ah, Beirut: Dâr al-Fikr.

al-Ju'fi, Muhammad ibn Ismail Abu Abdillah Al-Bukhāri. (1998). Al-Adab Al-Mufrād Bi Al-Ta'liqāt Juz 1 Cet I; Riyād; Maktabah Al-Ma'ārif.

al-Mâlîbary, Zainuddin Ibn Abd Aziz. (1980). Fath al-Mu'în, Kairo: Maktabah Dar alTuras.

al-Qardhawi, Yusuf. (2002). Fatwa-fatwa Kontemporer Jilid III, Cet I; Jakarta: Abdul Hayyi Al-Khatamī, Gema Insane Press.

al-Qārdawi, Yusuf. (2006). Fikih al-Zakah Juz 1 Al-Ḋaha: (t.p)

al-Sabiq, Sayyid. (t.th). Fiqh Sunnah, Juz I, Kairo: Maktabah Dar Al-Turas.

al-Wāhidī, Abi Al-Hasan ‘Ali ibn Ahmad, (1995). Tafsīr Al-Wajīz, Cet. I; Beirut Dār AlQālamī.

al-Yaman̄i, Nasywān ibn Saīd Al-Hamīra. (1999). Syamsul Al-'Ulum Wa Dawāu AlKalamī Al-Arabī Min Al-Kulum, Juz 5 Cet I; Beirut, Dar Al-Fikri Wa AlMu'așarah.

Bakry, Nazar. (1994). Problematika Pelaksanaan Fiqih Islam, Jakarta: PT Raja Grafindo Persansa.

Husen, Ibrahim. (1987). Ma Huwa Al-Maisir, Jakarta: IIQ.

Ibn Hambal, Abu Abdillah Ahmad ibn Muhammad. (2001). Musnad al-Imam Ahmad ibn Hambal, Juz 16. Cet I; Muassasatu al-Risālah.

Ibn Qāsim, Abdurrahman ibn Muhammad. (2005). Majmu’ Al-Fatāwāa, Juz 31. Madinah: Mujamma' Al-Malikī Fahd Litābā'ati Al-Mushaf Al-Syarīf. 
BUSTANUL FUQAHA: Jurnal Bidang Hukum Islam

Vol. 1, No. 3 (2020) : Hal. 390-415

Website: https://journal.stiba.ac.id

Jamāah Min al-'Ulamā. (1436 H). al-Mukhtașar Fī al-Tafsīr Al-Qur'an al-Karīm, Juz 1 Cet. III; Markaz Tafsīr Liddirāsāti al-Qurāniyah.

Jamâl, Ibrahim Muhammad. (1986). Fiqh al-Mar'ah al-Muslimah, Semarang: CV AsySyifa.

Kementrian Agama RI. (2017). Al-Qur'an dan Terjemahnya. Jakarta Timur: Ummul Qura.

Majma’ Al-Lugātu Al-Arabiyah Bi Al-Qāhirah. (t.th). Al-Mu ’jam Al-Wasīt, Juz 1 Dar AlDa'wah..

Muhammad Ali, Abu Ibrāhim. (1429 H). Undian Berhadiah Dalam Fiqih Islam, Cet I; Gresik, Pustaka Al-Furqān.

Nukhbah Min al-'Ulamā. (2006). al-Tafsir al-Muyassar, Cet II al-Madinah alMunawwarah: Majma' al-Malik Fahd

Suhendi, Hendi. (2008). Fiqih Mu'amalah, Jakarta: PT. Raja Grafindo Persada.

Syamsuddin, Muhammad Rasyīd ibn 'Alī Ridā ibn Muhammad. (1990). Tafsīr al-Qur'an al-Hakìm, Juz 7, Al-Haiah al-Mișriyyah al-‘āmmah Lilkutub.

Syarwat, Ahmad. (2011). Seri Fikih Kehidupan Cet 1; Jakarta DU Publishing

Umar Abdul Rahman, Umar bin Muhammad. (2016). Taysīr Kitāb al-așalat fì al-Fiqhi al-Islām Syabakatu al-Arūka.

Uwaidah, Kamil Muhammad. (1998). Fiqih Wanita, Jakarta: Pustaka al-Kautsar. 